\title{
Simulations of freshwater lens recharge and salt/freshwater interfaces using the HYDRUS and SWI2 packages for MODFLOW
}

\author{
Adam Szymkiewicz ${ }^{1 *}$, Anna Gumuła-Kawęcka ${ }^{1}$, Jirka Šimůnek ${ }^{2}$, Bertrand Leterme ${ }^{3}$, Sahila Beegum ${ }^{2}$, \\ Beata Jaworska-Szulc ${ }^{1}$, Małgorzata Pruszkowska-Caceres ${ }^{1}$, Wioletta Gorczewska-Langner ${ }^{1}$, \\ Rafael Angulo-Jaramillo ${ }^{4}$, Diederik Jacques ${ }^{3}$ \\ ${ }^{1}$ Gdańsk University of Technology, Faculty of Civil and Environmental Engineering, ul. Narutowicza 11, 80-233 Gdańsk, Poland. \\ ${ }^{2}$ University of California Riverside, 900 University Ave., Riverside, CA 92521, USA. \\ ${ }^{3}$ Engineered and Geosystems Analysis, Institute for Environment, Health and Safety, Belgian Nuclear Research Centre, Boeretang 200, \\ $2400 \mathrm{Mol}$, Belgium. \\ ${ }^{4}$ Laboratoire d'Ecologie des Hydrosystèmes Naturels et Anthropisés (LEHNA) UMR 5023, 3, rue Maurice Audin, 69518 Vaulx-en-Velin, \\ France. \\ * Corresponding author. E-mail: adams@pg.gda.pl
}

\begin{abstract}
The paper presents an evaluation of the combined use of the HYDRUS and SWI2 packages for MODFLOW as a potential tool for modeling recharge in coastal aquifers subject to saltwater intrusion. The HYDRUS package for MODFLOW solves numerically the one-dimensional form of the Richards equation describing water flow in variablysaturated media. The code computes groundwater recharge to or capillary rise from the groundwater table while considering weather, vegetation, and soil hydraulic property data. The SWI2 package represents in a simplified way variable-density flow associated with saltwater intrusion in coastal aquifers. Combining these two packages within the MODFLOW framework provides a more accurate description of vadose zone processes in subsurface systems with shallow aquifers, which strongly depend upon infiltration. The two packages were applied to a two-dimensional problem of recharge of a freshwater lens in a sandy peninsula, which is a typical geomorphologic form along the Baltic and the North Sea coasts, among other places. Results highlighted the sensitivity of calculated recharge rates to the temporal resolution of weather data. Using daily values of precipitation and potential evapotranspiration produced average recharge rates more than $20 \%$ larger than those obtained with weekly or monthly averaged weather data, leading to different trends in the evolution of freshwater-saltwater interfaces. Root water uptake significantly influenced both the recharge rate and the position of the freshwater-saltwater interface. The results were less sensitive to changes in soil hydraulic parameters, which in our study were found to affect average yearly recharge rates by up to $13 \%$.
\end{abstract}

Keywords: Groundwater recharge; Freshwater lenses; HYDRUS; SWI2; MODFLOW; Vadose zone.

\section{INTRODUCTION}

Groundwater recharge through the vadose zone is an important factor affecting salinity patterns in coastal aquifers. In particular, in view of possible climate change, increased water demands and sea level rise, the development of freshwater lenses supplied with infiltrated rainwater on top of saline aquifers is a subject of intense research (e.g., Werner et al., 2013). A large number of contributions have focused on freshwater lenses in deltaic regions, as well as on islands, peninsulas, or sandbars located in tropical, arid, and temperate climatic zones (e.g., Comte et al., 2014; Contractor and Jenson, 2000; Chang et al., 2016; De Louw et al., 2011; Eeman et al., 2017; Holding and Allen, 2015; Houben and Post, 2016; Illangasekare et al., 2006; Jocson et al., 2002; Mahmoodzadeh et al., 2014; Sadurski et al., 1987; Sinclair et al., 2016; Stuyfzand, 2016; Sulzbacher et al., 2012).

The actual amount of recharge reaching the groundwater table depends on several factors, including time-variable weather conditions, land use, hydraulic properties of the vadose zone, topographic relief, and the groundwater table depth. Thus, recharge is inherently variable in space and time and this variability may have a significant influence on freshwater-saltwater dynamics in shallow coastal aquifers (Mollema and Antonelli, 2013; Trglavcnik et al., 2016; Vandenbohede et al., 2014). Other studies highlighted the importance of such factors as water uptake by tree roots (Comte et al., 2014) or hydraulic properties and water storage in the vadose zone (Contractor and Jenson, 2000; Jocson et al., 2002). There is thus a need to include seasonal fluctuations of recharge in groundwater models for coastal aquifers (Eeman et al., 2012; Mollema and Antonellini, 2013; Oude Essink et al., 2010) and to integrate vadose zone processes more fully into groundwater models.

Vadose zone models transform weather data that are provided as input (precipitation and potential evapotranspiration) into recharge fluxes arriving at the groundwater table. The choice of the temporal resolution of weather data (hourly, daily, monthly, yearly) can significantly affect time distribution and values of recharge. This problem was investigated previously mainly within the context of solute transport through the unsaturated zone (e.g. Foussereau et al., 2001; Persson and Saifadeen, 2016; Vero et al., 2014), with results showing that using longer averaging periods (e.g., daily vs. hourly) of weather data leads to less recharge and longer solute travel times. A systematic study by Batalha et al. (2018) evaluated groundwater recharge in different climatic regions of Brazil. They found that recharge rates calculated using daily climatological data were up to 9 times larger than those obtained using yearly averages. On the other hand, saltwater intrusion studies are often performed using monthly (e.g., Mollema and Antonellini, 2013; Prieto et al., 2006) or yearly (e.g., Oude Essink et al., 2010) weather data. Thus, the question arises about the possible influence of the temporal resolution of weather data on modeling results. 
It is generally accepted that comprehensive representations of water flow in the vadose zone can be obtained using the Richards equation (e.g., Healy, 2010), although this approach generally does not account for some processes that may be important at the local scale, such as preferential flow (e.g., Šimůnek et al., 2003) or air entrapment (e.g., Szymańska et al., 2016). An extended form of the Richards equation can be used to describe flow under both unsaturated and saturated conditions, thereby offering a unified three-dimension (3D) description of flow for the entire subsurface domain. Numerical codes such as SUTRA (Voss and Provost, 2010), or HydroGeoSphere (Therrien et al., 2010) are based on this approach and include the capability to simulate density-dependent flow essential for saltwater intrusion modeling. However, due to high nonlinear nature of the Richards equation and the need for fine spatial discretizations close to the land surface, the requirements for computational power and time are often prohibitive for fully coupled saturated-unsaturated 3D models.

Alternatively, less complex models can be used also to describe flow in the vadose zone, especially close to the land surface. These models are often based on relatively simple water balance principles (e.g., SWAT (Neitsch et al., 2011) or HELP (Schroeder et al., 1994)) or kinematic wave routing (e.g., the UZF1 package for MODFLOW (Niswonger et al., 2006)). The usefulness of these type of models has been confirmed in a number of studies (e.g., Chang et al., 2016; Holding and Allen, 2015; Luoma and Okkonen, 2014). They are typically very efficient computationally. However, due to their simplified nature, they may not be able to represent properly some important features of unsaturated flow. For example, neither UZF1 nor HELP allows for upward flow due to capillary action, while SWAT greatly simplifies water flow below the root zone. Additionally, the kinematic wave model used in UZF1 is based on the assumption of a homogeneous soil profile, which is often not the case.

In addition to the above two groups of models, another possible modeling approach of intermediate complexity would be to couple a 3D (or 2D horizontal) model for flow in the saturated zone with one or more 1D models for flow in representative unsaturated zone soil profiles, based on the Richards equation. Such an intermediate approach would still allow for a wide range of unsaturated zone processes, but with less computational overhead compared to the complete $3 \mathrm{D}$ variablysaturated flow models. The intermediate concept was implemented in the HYDRUS package for MODFLOW (Beegum et al., 2018; Seo et al., 2007; Twarakavi et al., 2008), which is based on the widely-used standalone numerical HYDRUS-1D code (Šimůnek et al., 2008ab, 2016). HYDRUS-1D simulates the transient movement of water, solute, and heat in variably-saturated soil profiles using finite element discretization in space and fully implicit discretization in time. The model has been validated in a large number of applications (Šimůnek et al., 2008b, 2016), including several related to recharge (e.g., Scanlon et al., 2002; Šimůnek et al., 2016) and saltwater intrusion (Werner and Lockington, 2004).

The HYDRUS package for MODFLOW was originally written for MODFLOW-2000 (Seo et al., 2007). Its evaluation and comparison with other MODFLOW-related packages for vadose zone flow was presented by Twarakavi et al. (2008) and Bailey et al. (2013). Applications to regional scale groundwater flow, as well as comparisons with the UZF1 package, are described in Leterme et al. $(2013,2015)$. Currently, the package is being developed further in cooperation between research groups from the University of California Riverside, the Belgian Nuclear Research Centre (SCK•CEN), and the Gdańsk Univer- sity of Technology (Beegum et al., 2018). The most recent version of the HYDRUS package is compatible with MODFLOW-2005 (Harbaugh, 2005). So far, only a fraction of the processes implemented in the original standalone HYDRUS-1D program has been ported to HYDRUS for MODFLOW. Much potential exists for further enhancements, including features such as contaminant transport, macropore flow, or improved models of the hydraulic functions.

The SWI2 package (Bakker et al., 2013) is the latest release of the Seawater Intrusion (SWI) Package for MODFLOW. This package allows simulations of variable-density groundwater flow and seawater intrusion in multi-aquifer coastal systems. Vertically integrated variable-density flow is based on the Dupuit approximation in which an aquifer is vertically discretized into zones of differing densities, separated from each other by defined surfaces representing interfaces (Bakker et al., 2013). The simplified, sharp-interface approach to densitydependent flow implemented in the SWI and SWI2 packages allows for considerable savings of computer time, as compared to solutions of the coupled variable-density flow and salt transport equations. In fact, each aquifer can be represented by only a single layer of cells. However, the sharp-interface model neglects diffusion and dispersion processes, which may be important in some circumstances. Numerical tests (Dausman et al., 2010) showed that the sharp-interface models may not be realistic when considerable dispersion occurs across the interface, when the anisotropy ratio is very small, or in some systems where inversion occurs and a significant amount of vertical fingering is present.

Our research reported in this contribution has two main goals. The first objective is to carry out an evaluation of the HYDRUS package for MODFLOW as a tool for simulating recharge in conjunction with the SWI2 package (Bakker et al., 2013) for saltwater intrusion modeling. While HYDRUS-1D has been used previously in studies related to saltwater intrusion, the HYDRUS package for MODFLOW has to the best of our knowledge not yet been applied in this particular context. The second objective is to investigate the influence of selected factors on the amount of recharge as well as evolutions of the groundwater table and the saltwater-freshwater interface during the simulations. These factors include uncertainty in soil hydraulic parameters (describing the retention and hydraulic conductivity functions of unsaturated soils), the presence of vegetation, and the temporal resolution of weather data (precipitation and reference evapotranspiration).

\section{MATERIALS AND METHODS HYDRUS code}

Numerical simulations were performed using a modified version of MODFLOW-OWHM (Hanson et al., 2014), which includes both the SWI2 (Bakker et al., 2013) and HYDRUS packages for MODFLOW (Twarakavi et al., 2008). We used the updated version of HYDRUS for MODFLOW (Beegum et al., 2018), which represents an improvement over the original version as described by Seo et al. (2007) and Twarakavi et al. (2008), and which is compatible with MODFLOW-2005 and MODFLOW-OWHM. Here, we provide a more detailed description of the current version of the HYDRUS package, while details about MODFLOW-OWHM and SWI2 can be found in Hanson et al. (2014) and Bakker et al. (2013), respectively.

The HYDRUS package performs simulations of vertical flow in the vadose zone overlying the MODFLOW model domain. Simulations are carried out for a number of userdefined soil profiles. In principle, it is possible to associate a 
separate soil profile with each cell of the MODFLOW horizontal grid, but this approach may lead to unacceptably long simulation times for larger problems. Thus, it is recommended to divide the flow domain into a number of regions in such a way that each region encompasses several MODFLOW cells having approximately the same vadose zone flow and transport parameters. The division into regions should be based on such criteria as soil type, vegetation, depth to groundwater, and weather data. It is also possible to define HYDRUS profiles only for a part of the MODFLOW cells for which a more detailed description of unsaturated flow is required, while using alternative methods to specify recharge rates for the remaining cells.

The top of each HYDRUS profile corresponds with the soil surface, while the bottom should be located within the uppermost aquifer defined in MODFLOW, below the expected water table fluctuation zone. Each profile may consist of an arbitrary number of soil layers having different hydraulic properties. The number and position of nodes used to discretize each vadose zone profile are specified by the user. For reasons of numerical stability and efficiency, small nodal spacings (on the order of 1 $\mathrm{cm}$ ) close to the soil surface are recommended. Details of the numerical scheme used to solve the Richards equation in HYDRUS are given by Šimůnek et al. (2008a).

Boundary conditions at the soil surface are implemented as so-called atmospheric conditions, which can be described by the following set of inequalities (Neuman et al., 1974; Šimůnek et al., 2008a):

$$
I_{\max } \leq-K \frac{\partial h}{\partial z}-K \leq E_{\max }
$$

$h_{d r y} \leq h \leq h_{\text {pond }}$

where $I_{\max }$ is the maximum possible infiltration rate (equal to precipitation if interception is neglected), given as a negative number, $K$ is the soil hydraulic conductivity at the surface, $h$ is the pressure head, $z$ is the vertical coordinate (oriented positively upwards), $E_{\max }$ is the maximum possible evaporation rate (potential evaporation), $h_{\text {pond }}$ is the maximum ponding depth at the soil surface, and $h_{d r y}$ is the minimum allowed value of the pressure head at the surface. These values are provided by users at an arbitrary temporal resolution, and not related to the stress periods defined in MODFLOW. The type of the boundary condition at the soil surface is automatically switched between the flux and pressure head boundary conditions, depending upon the prevailing weather and soil conditions. When the pressure head boundary condition is used, the potential flux is reduced to the actual flux (e.g., actual infiltration and/or evaporation). Details about the numerical implementation of the atmospheric boundary conditions can be found in Šimůnek et al. (2008a).

Another important feature of the HYDRUS package is an explicit representation of water uptake by plant roots. The root zone depth and root density distribution is specified for each soil profile, according to available data on vegetation. The maximum potential transpiration rates are specified by the user at a temporal resolution matching the precipitation and evaporation data. At each HYDRUS time step, the current maximum transpiration rate is distributed among the nodes in the root zone, proportionally to the defined root density distribution, to calculate the nodal potential root water uptake. Actual root water uptake, appearing as a source term in the Richards equation, is obtained by multiplying potential root water uptake using a stress response function, which in turn depends on the soil water pressure head. For our simulations we used a simplification of the well-known stress response function of Feddes et al. (1978), as given by Huang et al. (2011). Resulting values of root water uptake are either equal to or smaller than the potential root water uptake.

\section{HYDRUS-MODFLOW coupling}

The sequential coupling of MODFLOW and HYDRUS involves exchanging information about the recharge rates and the position of the groundwater table. During each MODFLOW time step, the HYDRUS package is called to solve the 1D Richards equation for each defined soil profile. Due to the variability and nonlinearity of flow in the unsaturated zone, the HYDRUS solution is generally performed using much smaller time steps than the MODFLOW solution. HYDRUS time steps are adjusted automatically within a user-defined range according to the performance of the iterative solver. The initial condition for each soil profile is specified by users for the first MODFLOW time step. The atmospheric boundary condition at the top of each profile is used to represent precipitation, irrigation and/or evaporation as described above. The boundary condition at the bottom of each profile is given as the average value of the groundwater head in the uppermost aquifer, calculated for all MODFLOW cells associated with a particular soil profile.

The unsaturated flow simulation is performed for a time period corresponding to the current MODFLOW time step. Average flow through the bottom of the vadose zone profile during a particular MODFLOW time step is then used as the average recharge (or capillary rise) rate for a particular time step. This recharge rate is then included into the discretized equations for the MODFLOW cells corresponding to a given profile (in the same manner as recharge values defined in the $\mathrm{RCH}$ package). Next, the solution for saturated zone flow is obtained with MODFLOW for the new time level, thus providing new values of groundwater heads in the upper aquifer, with the solution proceeding to the next time step. Pressure head and water content distributions in each HYDRUS profile are updated next to reflect the new position of the water table and the vertical flux in the considered HYDRUS profile at the end of the previous MODFLOW time step (Beegum et al., 2018).

Note that the HYDRUS package for MODFLOW does not consider full coupling of saturated and unsaturated flow, such as in the VSF (Thoms et al., 2006), VS2DI (Healy, 2008), or SUTRA (Voss and Provost, 2010) codes. Rather, the HYDRUS package is now merely a tool to facilitate and improve estimations of infiltration and evapotranspiration fluxes, which otherwise could be achieved using the standalone HYDRUS1D code or other codes solving the 1D Richards equation, as implemented for example by Contractor and Jenson (2000) and Kamps et al. (2008). The applied loose coupling scheme does not allow complete consistency between the HYDRUS and MODFLOW solutions due to the three reasons, First, during each MODFLOW time step, the HYDRUS simulation is performed with a constant groundwater head at the bottom of the profile, which is subsequently updated instantaneously at the beginning of a new time step. In reality, the groundwater table varies continuously in time in response to vadose zone flow and other processes such as pumping. Second, the groundwater head at the bottom of each HYDRUS profile represents an average for all MODFLOW cells associated with a particular soil profile, while in reality it is spatially variable. And third, MODFLOW solves the groundwater flow equation for an unconfined aquifer using a value of specific yield $\left(S_{y}\right)$, 
which is defined by the user independently of the vadose zone simulations. The value of $S_{y}$ determines the change in the groundwater table position in response to the specified recharge flux. Consequently, the specific yield also determines the updated boundary condition at the bottom of each HYDRUS profile during the next time step. We are aware that the value of specific yield should be strongly related to the vadose zone conditions above the water table; this issue is a subject of ongoing research.

The simplifications mentioned above result of the need to compromise between accuracy and computational efficiency in the proposed approach. As a consequence, it is not possible to calculate a global mass balance for both the saturated and unsaturated zones. The mass balance should be considered separately for the MODFLOW groundwater domain (taking into account the coupled fluxed) and for each HYDRUS profile at each MODFLOW time step. In the simulations described below the HYDRUS and MODFLOW mass balance errors for all time steps were below $1 \%$.

\section{Simulation setup}

Simulations were carried out for a 2D cross-section through a sandy peninsula along the Polish Baltic coast, as shown in Fig. 1. Although the width of the peninsula was $600 \mathrm{~m}$, the solution domain extended offshore $200 \mathrm{~m}$ on each side. The elevation of the ground surface varied from $-5 \mathrm{~m}$ at the edges of the domain to $+5 \mathrm{~m}$ in the center of the peninsula, while the bottom of the aquifer was assumed to be horizontal at an elevation of $-40 \mathrm{~m}$. The MODFLOW grid consisted of a single row of 100 cells in a single layer representing the unconfined aquifer. The vertical boundaries and the bottom of the domain were assumed impermeable. A third-type boundary condition (a general head boundary, GHB) was prescribed on those parts of the soil surface that were below the sea level, similarly as in the examples described by Bakker et al. (2013), using the GHB package of MODFLOW. The total freshwater head, $H=h+z$, was assumed to be $0 \mathrm{~m}$ for the GHB cells, while the conductivity was set to $100 \mathrm{~m}^{2} / \mathrm{d}$. The SWI2 option ISOURCE was set to -2 for the GHB cells so that any water infiltrating into the aquifer was considered to be seawater, while water exfiltrating to the sea had the salinity corresponding to the upper part of the cell. In all simulations, the number of salinity zones in the SWI2 package was set to 2 (i.e., a single zeta-surface was defined). The density of freshwater $\left(\rho_{f}\right)$ was $1 \mathrm{~g} / \mathrm{cm}^{3}$, and the density of saltwater $\left(\rho_{s}\right)$ was $1.0065 \mathrm{~g} / \mathrm{cm}^{3}$, typical for south Baltic sea water. The aquifer was assumed to be isotropic and homogeneous with a saturated conductivity $\left(K_{s}\right)$ of $10 \mathrm{~m} /$ day and a specific yield $\left(S_{y}\right)$ of 0.25 .

The central (land) part of the aquifer was subject to recharge from precipitation. Simulations of vadose zone flow were carried out using the HYDRUS package. Two regions with representative soil profiles were defined based on the average depth to the groundwater (GW) table. Region 1 included two 200-m wide strips of land parallel to the shoreline on each side of the peninsula where the GW table was up to $2 \mathrm{~m}$ deep on average. Region 2 consisted of the central $200 \mathrm{~m}$ of land where the GW table was expected to be about 4 to $5 \mathrm{~m}$ deep. The soil profiles were discretized using 41 nodes in Region 1 and 81 nodes in Region 2. The vertical node spacing was non-uniform, ranging from $1 \mathrm{~cm}$ close to the ground surface to $9 \mathrm{~cm}$ at the bottom of the profile.

The simulations were performed for three types of sand, characterized by the van Genuchten-Mualem hydraulic functions of the following form:

$$
\begin{aligned}
& \theta(h)=\theta_{R}+\left(\theta_{S}-\theta_{R}\right)\left[1+(\alpha|h|)^{n}\right]^{-m} \\
& K(h)=K_{S} K_{R}(h)=K_{S} \frac{\left\{1-(\alpha|h|)^{n-1}\left[1+(\alpha|h|)^{n}\right]^{-m}\right\}^{2}}{\left[1+(\alpha|h|)^{n}\right]^{m / 2}}
\end{aligned}
$$

where $\theta$ is the volumetric water content, $\theta_{S}$ is the water content at field saturation, $\theta_{R}$ is the residual water content, $h$ is the soil water pressure head (negative in the unsaturated zone), $K$ is the hydraulic conductivity, $K_{S}$ is the hydraulic conductivity at field saturation, $K_{R}$ is the relative hydraulic conductivity, and $\alpha, n$ and $m$ are fitting parameters (with $m=1-1 / n$ ). Values of the soil hydraulic parameters are listed in Table 1 . The first set, with a relatively high saturated conductivity $(400 \mathrm{~m} / \mathrm{d})$, is denoted as medium sand in the database of VS2DTI and VS2DHI codes (Hsieh et al., 1999) and was used e.g. by Dan et al. (2012). While such a high hydraulic conductivity is not typical for vertical flow in the vadose zone (except macropore flow), we include this set as an example of highly permeable material. The second set, denoted here as fine sand, is reported by Carsel and Parrish (1988) as an average set of parameters for sand according to the USDA textural division. Similarly, the third set represents an average set of parameters for a loamy sand according to the USDA classification (Carsel and Parrish, 1988). In the following section, we report results obtained for each of these three soil types. Note that the change in hydraulic

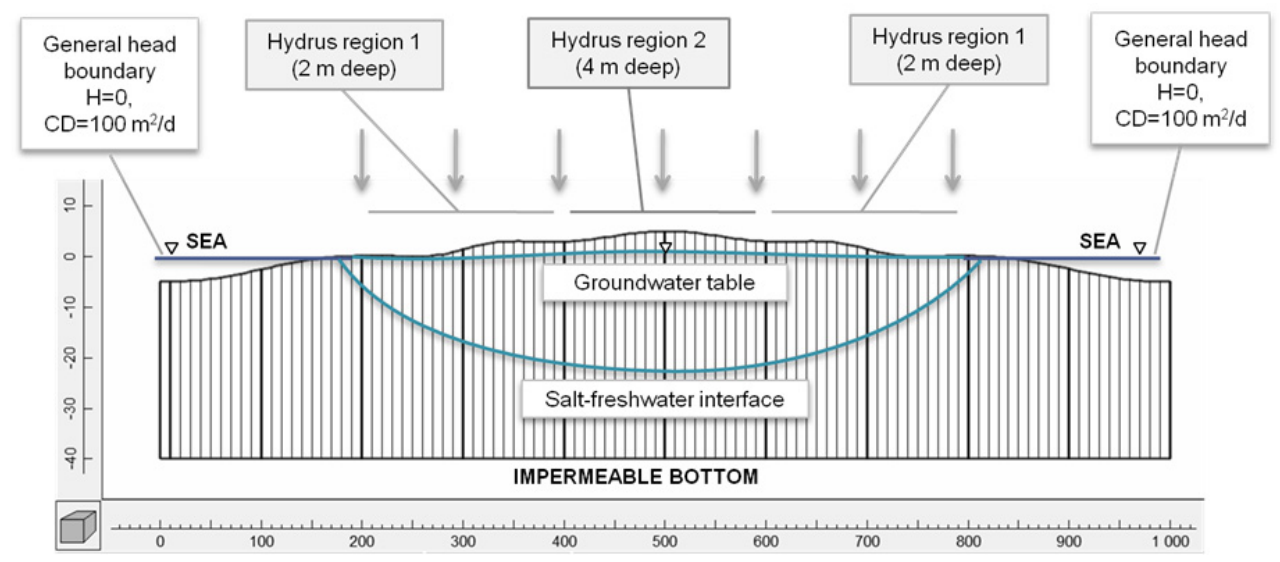

Fig. 1. Assumed flow domain and specified boundary conditions $(\mathrm{CD}=$ conductance $)$. 
parameters affected only the HYDRUS simulations for the vadose zone. The values of specific yield and the horizontal hydraulic conductivity in the aquifer were kept the same for all simulations. Thus, we neglected the influence of unsaturated flow on the specific yield, as explained above.

The initial condition for each simulation was obtained by running the MODFLOW/HYDRUS simulation for a period of 40000 days with a constant value of the infiltration flux (equal to the assumed recharge rate) imposed at the soil surface. The infiltration flux was specified as $300 \mathrm{~mm} / \mathrm{yr}$, based on estimates given by Dyck and Chardabellas (1963) (cited in Hölting and Coldewey, 2013) for sands with a sparse plant cover (about $60 \%$ of yearly precipitation). A long warm-up period was used because of the need to obtain the steady position of the interface with the SWI2 package, which generally requires more than 100 years (see Examples 3 and 4 in the documentation of SWI2). A warm-up period for the vadose zone simulations was also necessary, but it is much shorter, on the order of a single year. As a basic check, we compared the steady-state results obtained with the HYDRUS package with a constant infiltration rate to the results obtained with the RCH MODFLOW package. This package allows one to input a user-specified rate of recharge at the water table. While the results are not shown here, the agreement in terms of both the groundwater table elevation and the saltwater-freshwater interface position was very good (differences in the position of the groundwater table and the fresh-salt interface in the center of the domain were less that 1.5 $\mathrm{cm}$, while the elevations agreed with the Ghyben-Herzberg formula (Verruijt, 1968)).

Simulations were performed for a 5-year period using the available weather data from Gdańsk (2011-2015), starting from the initial steady-state conditions. Daily values of the reference potential evapotranspiration $\left(E T_{0}\right)$ for the simulation period are shown in Figure 2, while the daily precipitation values are shown in Figs. 3, 5 and 7. Average annual precipitation during the 5 -year period was $550 \mathrm{~mm} / \mathrm{yr}$ and the average annual $E T_{0}$ $317 \mathrm{~mm} / \mathrm{yr}$. $E T_{0}$ was estimated using the method of Grabarczyk, developed in Poland (Grabarczyk and Żarski, 1992), which gives evapotranspiration values somewhat lower

Table 1. Parameters of the van Genuchten - Mualem hydraulic model for the soils used in this study.

\begin{tabular}{|l|c|c|c|}
\hline Parameter & Medium sand & Fine sand & Loamy sand \\
\hline$\theta_{R}$ & 0.022 & 0.045 & 0.057 \\
\hline$\theta_{S}$ & 0.375 & 0.430 & 0.410 \\
\hline$K_{S}[\mathrm{~m} / \mathrm{d}]$ & 400 & 10 & 3.5 \\
\hline$\alpha[1 / \mathrm{m}]$ & 4.31 & 14.50 & 12.40 \\
\hline$n=3.08$ & 3.10 & 2.68 & 2.28 \\
\hline
\end{tabular}

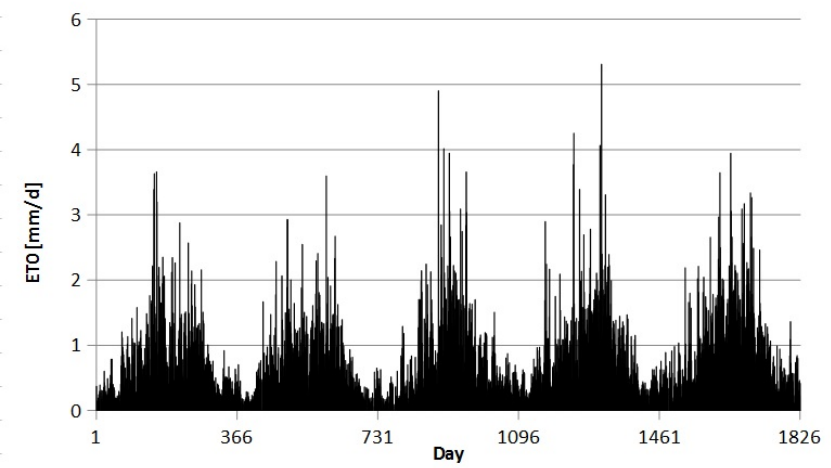

Fig. 2. Daily reference evapotranspiration rates for the 5-year simulation period.

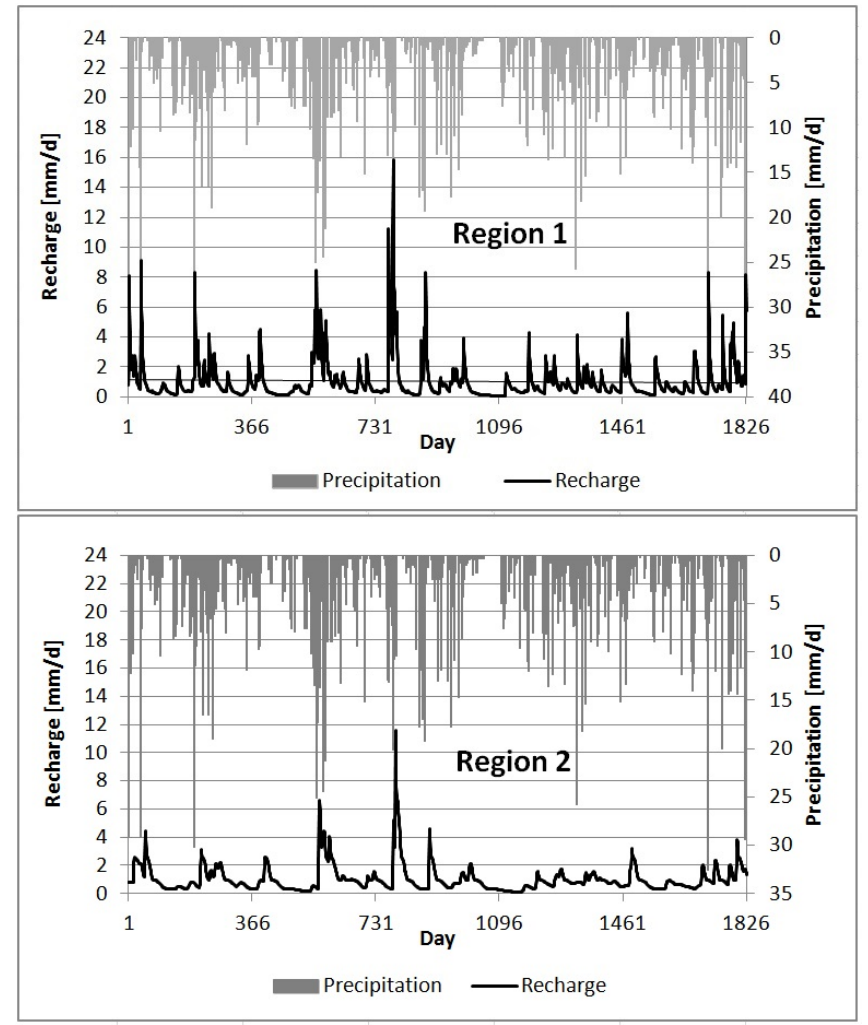

Fig. 3. Daily values of recharge for fine sand without vegetation, calculated using daily weather data; top: HYDRUS region 1, bottom: HYDRUS region 2.
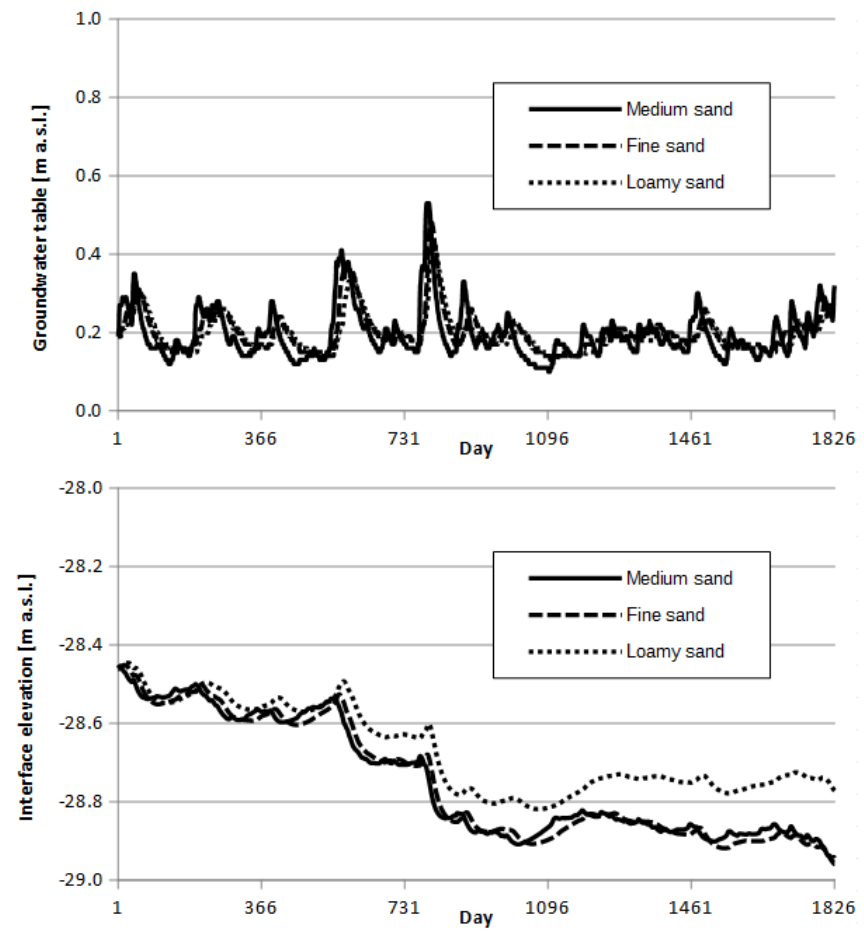

Fig. 4. Evolution of the water table position (top) and the freshwater/saltwater interface for different types of sand, using daily weather data and assuming no vegetation.

than the widely used Penman-Monteith FAO equation. The formula requires only daily values of the average air temperature and the average vapor pressure deficit. 


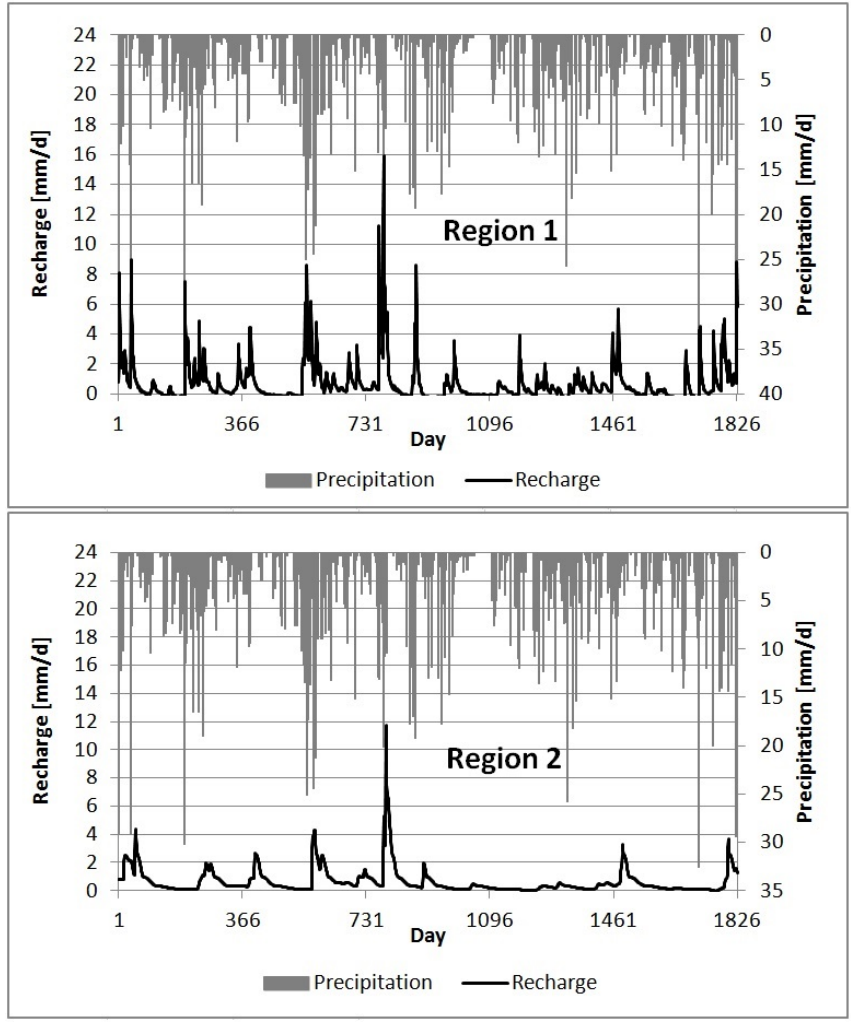

Fig. 5. Daily values of recharge for fine sand with vegetation, calculated using daily weather data in two HYDRUS regions; top: HYDRUS region 1, bottom: HYDRUS region 2.
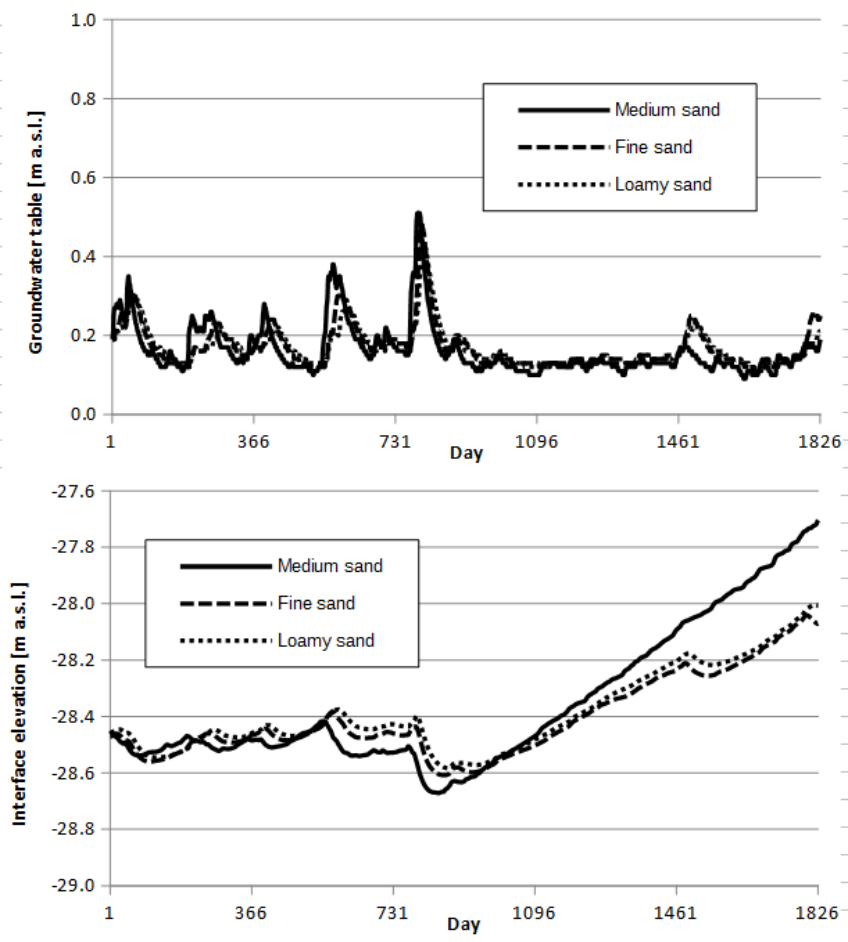

Fig. 6. Evolution of the water table position (top) and the freshwater/saltwater interface for different types of sand, using daily weather data and assumed the presence of vegetation.

The total evapotranspiration flux includes both evaporation from the soil surface and transpiration of water taken up by plant roots from deeper soil layers. Several studies (e.g., Comte at al., 2014; Kamps et al., 2008) reported that water uptake
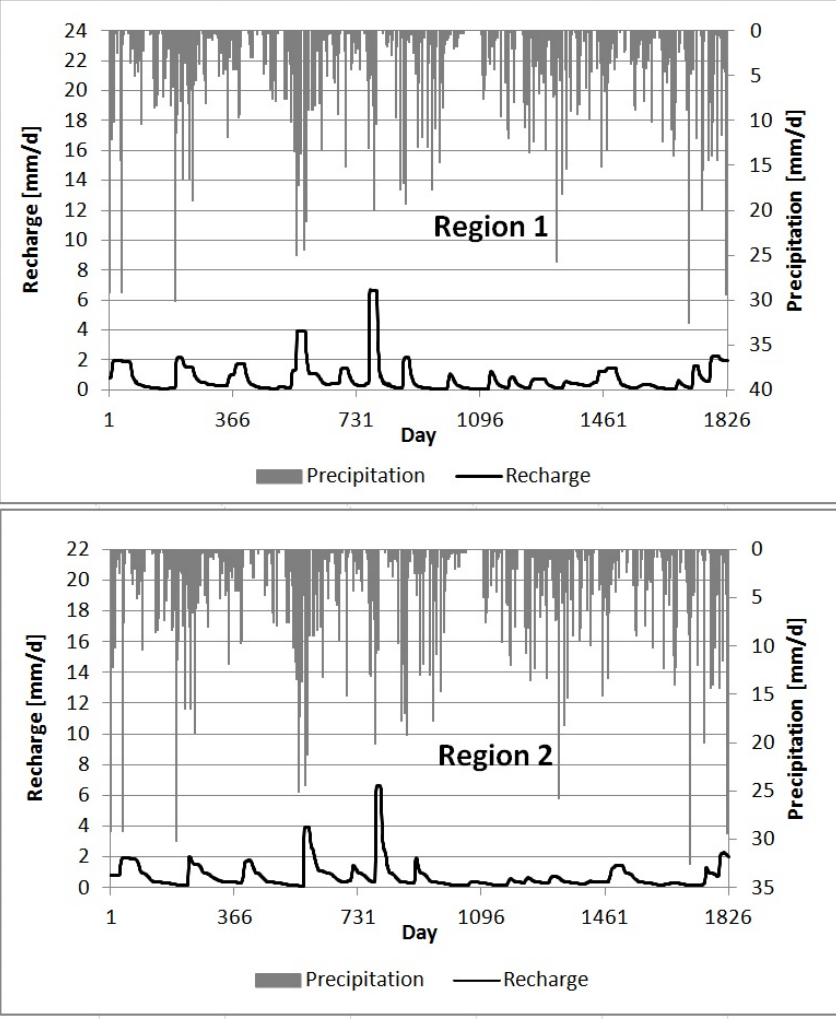

Fig. 7. Daily values of recharge for fine sand without vegetation, calculated using monthly weather data; top: HYDRUS region 1, bottom: HYDRUS region 2.

by vegetation is an important factor influencing groundwater resources of freshwater lenses. In order to account for this, we performed two series of simulations. In the first series, we neglected the presence of plants and assumed that $E T_{0}$ was equal to potential evaporation. In the second series, the reference evapotranspiration was distributed as a source term over the root zone, i.e., $E T_{0}$ corresponded to potential transpiration (interception was not considered). While both of these cases were significant simplifications of reality, they can be considered as indicators for the possible range of variability of recharge for a varying soil cover by vegetation. We assumed that the depth of the root zone was $2 \mathrm{~m}$, with the root density distribution decreasing linearly from a maximum value at the soil surface to zero at a depth of $2 \mathrm{~m}$. For the stress response function, which describes the reduction in water uptake due to decreasing pressure heads in unsaturated soil, we used the model of Huang et al. (2011), which is a simplified version of the well-known formulation by Feddes et al. (1978). In this approach, root water uptake is assumed to be maximum for pressure heads larger than $h_{1}$ (equal to $-3 \mathrm{~m}$ in our study), zero for pressure heads less than the wilting point (assumed at $h_{2}=-150 \mathrm{~m}$ ), and changing linearly for pressure heads between these two values. Such a model is considered representative of coniferous forests (see Huang et al., 2011, and references therein). More details on the implementation of root water uptake in HYDRUS-1D can be found in Šimůnek et al. (2008a). The two scenarios represent typical conditions of coastal sandbars of the Baltic coast, which can be covered by bare dunes, grassland, or sparse pine forests.

The coupled codes were also used to investigate the effect of the temporal resolution of weather data. We used either daily, weekly, or monthly averages of the precipitation and evapotranspiration rates. Regardless of the temporal resolution of the 
weather data, we used a constant MODFLOW time step of 1 day and allowed the time steps in HYDRUS to vary within a range from $10^{-5}$ to 1 day. All simulations assumed a ponding depth of zero and a minimum soil water pressure head at the soil surface of $-10000 \mathrm{~m}$. The input data for the groundwater model were partly prepared using the ModelMuse interface (Winston, 2009). Since ModelMuse does not support HYDRUS for MODFLOW, all data required by this package were prepared using spreadsheet software.

\section{Sensitivity analysis}

Additionally, a sensitivity analysis was performed by changing values of the van Genuchten-Mualem parameters of fine sand, one at a time, according to the following scheme: $K_{S}$ was decreased or increased by one order of magnitude $\left(K_{S}=1\right.$ or $100 \mathrm{~m} / \mathrm{d}), \alpha$ was changed by $+/-50 \%(\alpha=7.25$ and 21.75 $\left.\mathrm{m}^{-1}\right)$, and $n$ was changed by $+/-0.5(n=2.18$ and 3.18). Such a range of parameter variability may reflect uncertainty in the unsaturated zone parameters as measured in the field or estimated from basic soil data via pedotransfer functions. For example, a study by Meyer et al. (1997) provides the following range of variability for $\alpha$ and $n$ in the USDA sand textural group: $K_{S}=0.3 \mathrm{~m} / \mathrm{d}$ to $16 \mathrm{~m} / \mathrm{d}, \alpha=6.87$ to $22.6 \mathrm{~m}^{-1}$, and $n=$ 1.95 to 3.62 . According to other authors, the hydraulic conductivity of sands may vary in a wider range. For example, Freeze and Cherry (1979) gave values of $K_{S}$ from about 1 to $1000 \mathrm{~m} / \mathrm{d}$ for clean sands. These intervals are wider than those assumed in our study; combinations of hydraulic parameters that differ from the above intervals may still be considered physically admissible.

\section{RESULTS AND DISCUSSION}

Results obtained for the various scenarios described in the previous section are presented in Tables 2 and 3 and Figures 3 to 8 . The different scenarios are compared in terms of the average yearly recharge rate during the 5-year simulation period, daily recharge values in the two HYDRUS regions, and evolutions of the groundwater table and the freshwater-saltwater interface in the center of the domain.

\section{Influence of the soil hydraulic properties}

The results of simulations performed using daily values of precipitation and reference evaporation for the three types of sand are presented in Table 2 and Figures 3 and 4. For these simulations we neglected the presence of vegetation. This means that the maximum evaporation flux at the soil surface was set to $E T_{0}$ as indicated in the previous section. Table 2 shows average annual values of recharge computed for the 5year period. They varied from $476 \mathrm{~mm} / \mathrm{yr}$ for medium sand to $416 \mathrm{~mm} / \mathrm{yr}$ for loamy sand, which corresponds to a relative difference of about $13 \%$. Figure 3 shows daily values of recharge in two regions, obtained using the fine sand hydraulic parameters. The distribution of recharge was found to be highly variable in time, generally following the pattern of precipitation. However, it can be seen that the depth of the vadose zone has a visible influence on the temporal distribution of recharge and its maximum daily values. In Region 2, where the depth to groundwater was larger than in Region 1, the recharge distribution was much smoother throughout the year, with peak values largely reduced. On the other hand, recharge rates between precipitation periods were larger in Region 2 because of longer redistribution time of soil moisture in deeper profiles.
Table 2. Average annual recharge rates $[\mathrm{mm} / \mathrm{yr}]$ obtained for different simulation settings.

\begin{tabular}{|l|c|c|c|}
\hline Scenario & Medium sand & Fine sand & Loamy sand \\
\hline $\begin{array}{l}\text { Daily weather data } \\
\text { No vegetation }\end{array}$ & 476 & 449 & 416 \\
\hline $\begin{array}{l}\text { Daily weather data } \\
\text { With vegetation }\end{array}$ & 359 & 315 & 306 \\
\hline $\begin{array}{l}\text { Weekly averaged weather data } \\
\text { No vegetation }\end{array}$ & 370 & 354 & 341 \\
\hline $\begin{array}{l}\text { Weekly averaged weather data } \\
\text { With vegetation }\end{array}$ & 317 & 304 & 301 \\
\hline $\begin{array}{l}\text { Monthly averaged weather data } \\
\text { No vegetation }\end{array}$ & 338 & 326 & 318 \\
\hline $\begin{array}{l}\text { Monthly averaged weather data } \\
\text { With vegetation }\end{array}$ & 338 & 326 & 318 \\
\hline
\end{tabular}

Table 3. Minimum $\left(\zeta_{\min }\right)$ and maximum $\left(\zeta_{\max }\right)$ elevations of the freshwater-saltwater interface and the average annual recharge rate for different values of the soil hydraulic parameters.

\begin{tabular}{|l|c|c|c|}
\hline \multicolumn{1}{|c|}{ Scenario } & $\zeta_{\min }[\mathrm{m}]$ & $\zeta_{\max }[\mathrm{m}]$ & $\begin{array}{c}\text { Average recharge } \\
{[\mathrm{mm} / \mathrm{yr}]}\end{array}$ \\
\hline $\begin{array}{l}\text { Fine sand } \\
\text { (Basic case) }\end{array}$ & -28.96 & -28.45 & 449 \\
\hline$K_{s}=100 \mathrm{~m} / \mathrm{d}$ & -29.02 & -28.45 & 461 \\
\hline$K_{s}=1 \mathrm{~m} / \mathrm{d}$ & -28.88 & -28.45 & 432 \\
\hline$\alpha=29 / \mathrm{m}$ & -29.11 & -28.45 & 474 \\
\hline$\alpha=7.25 / \mathrm{m}$ & -28.83 & -28.45 & 423 \\
\hline$n=3.08$ & -29.07 & -28.45 & 468 \\
\hline$n=2.08$ & -28.79 & -28.45 & 405 \\
\hline
\end{tabular}
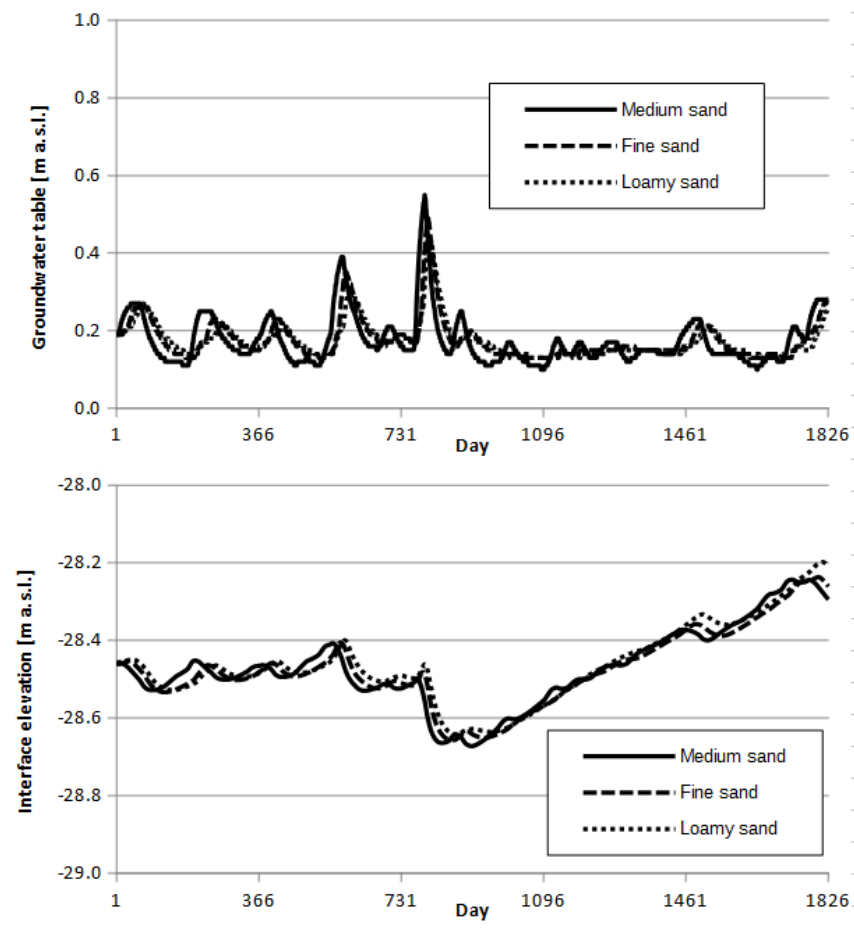

Fig. 8. Evolution of the water table position (top) and the freshwater/saltwater interface for different types of sand, using monthly weather data and assuming no vegetation.

As shown in Figure 4, the water table fluctuated following periods of high and low recharge, with a maximum amplitude of about $0.4 \mathrm{~m}$. The freshwater-saltwater interface also showed seasonal fluctuations, with a general decreasing trend. The final position of the interface was about $0.5 \mathrm{~m}$ lower than the initial position. This can be explained by the fact that average yearly 
recharge rates during the simulation period (from $416 \mathrm{~mm} / \mathrm{yr}$ to $476 \mathrm{~mm} / \mathrm{yr}$ ) were significantly higher that the recharge rate used obtain the initial steady-state condition $(300 \mathrm{~mm} / \mathrm{yr})$. The results shown in Figure 4 are similar for all three soil types, except that for loamy sand the interface elevation decreased at a lower rate than for medium and fine sand. We also note that recharge values were larger during the first 3 years of the simulations, resulting in a visible lower position of the interface. In contrast, the last 2 years were characterized by less recharge and more stable positions of the water table and the interface. The simulated position of the interface was generally higher than its elevation calculated using the Ghyben-Herzberg formula for a particular water table position. While the GhybenHerzberg approach assumes steady-state conditions, numerical simulations represent transient conditions. A notable time lag exists in the adjustment of the interface location for varying positions of the water table.

Results of the sensitivity analysis are presented in Table 3. The range of variability of average recharge rate and the final (minimum) position of the interface were consistent with the range of variability observed for the three sandy soils obtained earlier. An increase in any parameter (i.e., $K_{S}, \alpha$, or $n$ ) produced an increase in recharge and a decrease in the final position of the interface. Modifying $K_{S}$ by an order of magnitude produced a change of less than $4 \%$ in the average yearly recharge. Changing the van Genuchten parameter $\alpha$ by a factor of two resulted in variations in recharge of less than $6 \%$. On the other hand, increasing or decreasing $n$ by $19 \%$ produced a $4.2 \%$ increase and a $9.9 \%$ decrease in the average recharge rate, respectively. We hence conclude that, for our particular setting, the most sensitive parameter was $n$ since relatively small changes of its value were found to have a significant effect on recharge.

\section{Influence of water uptake by plant roots}

The second series of simulations assumed that the evapotranspiration flux was distributed over a 2-m deep root zone. Results of these simulations are summarized in Table 2 . The data show that root water uptake has a pronounced effect on recharge, and consequently also on the saltwater-freshwater interface position. Average yearly recharge rates decreased to values between 306 and $351 \mathrm{~mm} / \mathrm{yr}$, corresponding to a reduction of 24 to $30 \%$ compared to scenarios without vegetation. Relative differences in the average recharge rates of various soils were slightly larger than those for corresponding cases without vegetation (16\% vs. $13 \%)$.

The reduction in recharge due to vegetation is also reflected in the daily values of recharge shown in Figure 5. In contrast to the previous case, the elevation of the freshwater-saltwater interface increased during the simulation period (Fig. 6) for all three soils. The increase was particularly visible during the last two years, characterized by smaller recharge rates, which is consistent with the results for the scenarios without vegetation. Also, in this case, one can see somewhat larger differences between soil types in terms of the interface position. The highest final elevation of the interface was obtained for medium sand.

\section{Influence of the temporal resolution of weather data}

In order to investigate the effects of the temporal resolution of weather data, simulations were carried out using weekly and monthly averaged precipitation and reference evapotranspiration rates. The resulting values of average annual recharge are reported in Table 2. For the bare soil scenarios with weekly and monthly averaged meteorological data, the recharge rate decreased by about 20 and $27 \%$, respectively. Daily recharge values are shown in Figure 7 for the bare fine sandy soil and monthly averaged weather data. The plots show that the recharge patterns are distinctly different from those in Figure 3. As expected, fluctuations were smoothed to a large extent. The episodic nature of recharge, reported in the literature (e.g., Hunt et al., 2008; Smerdon et al., 2008), is lost when precipitation values are averaged over longer time periods. Similar conclusions on the influence of time averaging of the weather data were also presented by Batalha et al. (2018). These authors found that using long-term averages of precipitation and evapotranspiration will lead to severe underestimates of the recharge rates as compared to the use of daily data. Their results for semi-arid region in Brazil differed by a factor of 9 between simulations using daily and yearly averages of weather data. The discrepancy was found to be particularly significant for coarsetextured soils, which corroborates the results of our study.

The influence of the temporal resolution of weather data was found to be significantly smaller for the scenarios with vegetation. Table 2 shows that the maximum differences in average annual recharge were only about $13 \%$ for medium sand. In contrast to the case of bare soil (no vegetation), using monthly averaged weather data did lead to higher recharge rates than weekly averages. While this could be explained by a more complex pattern of water flow in the presence of a relatively deep root zone, these interactions remain to be investigated further. For the setting considered in this study, monthly averages of weather data produced nearly the same values of recharge for the cases with and without vegetation (differences were less than $1 \mathrm{~mm} / \mathrm{yr}$ ).

Table 2 also shows that the influence of soil hydraulic parameters on recharge decreases when weather data are averaged over longer time periods. While relative differences in recharge between the three types of sand for the daily data were about $13 \%$, they were only about $8 \%$ and $6 \%$ for the weekly and monthly averaged data, respectively. Sensitivity analysis with respect to the hydraulic parameters $K_{S}, \alpha$, and $n$ were also carried out for the weekly and monthly weather data. While details are not further reported here, the obtained ranges of recharge values were similar to the ranges shown in Table 2 for the three types of sand. Similarly as for daily data, increasing $K_{S}, \alpha$, or $n$ produced a slightly higher recharge rates when weekly or monthly weather data were used, with the $n$ parameter seemingly being the most sensitive parameter.

\section{CONCLUSIONS}

Based on preliminary evaluations carried out in this study, we consider the HYDRUS package for MODFLOW to be a promising tool for integrating vadose zone processes in a saturated groundwater flow model accounting for saltwater intrusion. This package allows calculations of spatially and temporally variable recharge rates using the physically-based Richards equation and an appropriate set of water retention and hydraulic conductivity functions characterizing vadose zone flow processes, and accounting for interactions with groundwater.

Our simulations indicated that for the particular system considered in this study, changes in soil hydraulic parameters had a moderate influence on the final position of the groundwater table and the freshwater-saltwater interface. This may explained by the fact that we considered only sandy soils, which are characterized by low water holding capacities and relatively high hydraulic conductivities. The sensitivity analysis showed that 
the recharge rates are affected more by the $\alpha$ and $n$ parameters of the van Genuchten function than by the hydraulic conductivity, which for our study was not the limiting factor for water infiltration. On the other hand, the results were influenced more significantly by the temporal resolution of the weather data and by the presence of vegetation (i.e., land use). The use of monthly and weekly averaged values of precipitation and potential evaporation led to recharge rates that were more than $20 \%$ smaller than those obtained using daily values. Similarly, when the potential evapotranspiration rate was distributed over the root zone instead of being assigned to the soil surface (i.e., vegetated versus unvegetated soil surfaces), the resulting recharge rates decreased by more than $24 \%$. Differences in the recharge rate directly influenced the evolution of the saltwaterfreshwater interface. For the scenarios with daily weather data and no vegetation, the position of the interface decreased with time due to relatively large recharge (larger than the initial steady-state value). The opposite trend was observed for scenarios with vegetation or for weekly and monthly averaged precipitation and evaporation data, which produced reductions in the recharge rate and upward displacement of the freshwatersaltwater interface.

Acknowledgements. This work has been supported by the National Science Centre, Poland, in the framework of project 2015/17/B/ST10/03233 "Groundwater recharge on outwash plain". Weather data were obtained from a station operated by the Department of Hydraulic Engineering, Faculty of Civil and Environmental Engineering, Gdańsk University of Technology.

The authors would like to thank two reviewers for their detailed and insightful remarks, which helped to improve the manuscript.

\section{REFERENCES}

Bailey, R.T., Morway, E.D., Niswonger, R.G., Gates, T.K., 2013. Modeling variably saturated multispecies reactive groundwater solute transport with MODFLOW-UZF and RT3D. Ground Water, 51, 5, 752-761. DOI: 10.1002/ird.1699.

Bakker, M., Schaars, F., Hughes, J.D., Langevin, C.D., Dausman, A.M., 2013. Documentation of the seawater intrusion (SWI2) package for MODFLOW. USGS Numbered Series "Techniques and Methods" 6-A46. US Geol. Survey, Reston, VA, USA.

Batalha, M.S., Barbosa, M.C., Faybishenko, B., van Genuchten, M.Th., 2018. Effect of temporal averaging of meteorological data on predictions of groundwater recharge. Journal of Hydrology and Hydrodynamics, 66, 2, 143-152.

Beegum, S., Šimůnek, J., Szymkiewicz, A., Sudheer, K.P., Nambi, I.M., 2018. Implementation of solute transport in the vadose zone into the 'HYDRUS package for MODFLOW'. Groundwater, (under review).

Carsel, R.F., Parrish, R.S., 1988. Developing joint probability distributions of soil water retention characteristics. Water Resources Research, 24, 5, 755-769.

Chang, S.W., Nemec, K., Kalin, L., Clement, T.P., 2016. Impacts of climate change and urbanization on groundwater resources in a barrier island. Journal of Environmental Engineering, D4016001.

Comte, J.C., Join, J.L., Banton, O., Nicolini, E., 2014. Modelling the response of fresh groundwater to climate and vegetation changes in coral islands. Hydrogeology Journal, 22,8,1905-1920.
Contractor, D.N., Jenson, J.W., 2000. Simulated effect of vadose infiltration on water levels in the Northern Guam Lens Aquifer. Journal of Hydrology, 229, 3, 232-254.

Dan, H.C., Xin, P., Li, L., Li, L., Lockington, D., 2012. Capillary effect on flow in the drainage layer of highway. pavement. Canadian Journal of Civil Engineering, 39, 6, 654-666.

Dausman, A., Langevin, C., Bakker M., Schaars, F., 2010. A comparison between SWI and SEAWAT - the importance of dispersion, inversion and vertical anisotropy. In: Proceedings of the 21st Salt Water Intrusion Meeting, Azores, Portugal.

De Louw, P.G., Eeman, S., Siemon, B., Voortman, B.R., Gunnink, J., Van Baaren, E.S., Oude Essink, G., 2011. Shallow rainwater lenses in deltaic areas with saline seepage. Hydrology and Earth System Sciences, 15, 36593678.

Dyck, S., Chardabellas, P., 1963. Wege zur Ermittlung der nutzbaren Grundwasserreserven. Ber. Geol. Ges. DDR, 8, 245-262.

Eeman, S., Zee, S.V.D., Leijnse, A., De Louw, P.G.B., Maas, C., 2012. Response to recharge variation of thin rainwater lenses and their mixing zone with underlying saline groundwater. Hydrology and Earth System Sciences, 16, 10, 3535-3549.

Eeman, S., De Louw, P.G.B., Van der Zee, S.E.A.T. M., 2017. Cation exchange in a temporally fluctuating thin freshwater lens on top of saline groundwater. Hydrogeology Journal, $25,1,223-241$

Feddes, R.A., Kowalik, P.J., Zaradny, H., 1978. Simulation of Field Water Use and Crop Yield. John Wiley \& Sons, New York, NY.

Foussereau, X., Graham, W.D., Akpoji, G.A., Destouni, G., Rao, P.S.C., 2001. Solute transport through a heterogeneous coupled vadose-saturated zone system with temporally random rainfall. Water Resources Research, 37, 6, 15771588.

Freeze, R.A., Cherry, J.A., 1979. Groundwater. Prentice Hall.

Grabarczyk, S., Żarski, J., 1992. Próba statystycznej weryfikacji niektórych wzorów określających ewapotranspirację potencjalną. [An attempt at statistical verification of selected formulae estimating potential evapotranspiration.] Zeszyty Naukowe Akademii Techniczno Rolniczej w Bydgoszczy (Rolnictwo). (in Polish.)

Hanson, R., Boyce, S., Schmid, W., Hughes, J., Mehl, S., Leake, S., Maddock III, Th., Niswonger, R., 2014. OneWater Hydrologic Flow Model (MODFLOW-OWHM), Techniques and Methods 6-A51. US Geological Survey, Reston, VA, USA. Available from: http://dx. DOI: org/10.3133/tm6A51.

Harbaugh, A.W., 2005. MODFLOW-2005, the US Geological Survey modular ground-water model: the ground-water flow process. US Department of the Interior, US Geological Survey, Reston, VA, USA, pp. 6-A16.

Healy, R.W., 2008. Simulating water, solute, and heat transport in the subsurface with the VS2DI software package. Vadose Zone Journal, 7, 632-639.

Healy, R.W., 2010. Estimating Groundwater Recharge. Cambridge University Press, Cambridge, UK, 245 p.

Holding, S., Allen, D.M., 2015. From days to decades: numerical modelling of freshwater lens response to climate change stressors on small low-lying islands. Hydrology and Earth System Sciences, 19, 2, 933-949. 
Hölting, B., Coldewey, W.G., 2013. Hydrogeologie: Einführung in die allgemeine und angewandte Hydrogeologie. Springer-Verlag.

Houben, G., Post, V.E.A., 2016. How long does the recovery of a freshwater lens take after a massive saltwater inundation? Experiences from the island of Baltrum, Germany, after the 1962 flood disaster. In: Proceedings of 24th Salt Water Intrusion Meeting and the 4th Asia-Pacific Coastal Aquifer Management Meeting, 4-8 July 2016, Cairns, Australia.

Hsieh, P.A., Wingle, A.W., Healy, R.W., 1999. VS2DI: A graphical software package for simulating fluid flow and solute or energy transport in variably saturated porous media. USGS Water-Resources Investigation Report 994130. US Geological Survey, Reston, USA.

Huang, M., Barbour, S.L., Elshorbagy, A., Zettl, J.D., Si, B.C., 2011. Water availability and forest growth in coarse-textured soils. Canadian Journal of Soil Science, 91, 2, 199-210.

Hunt, R.J., Prudic, D.E., Walker, J.F., Anderson, M.P., 2008. Importance of unsaturated zone flow for simulating recharge in a humid climate. Ground Water, 46, 4, 551-560.

Illangasekare, T., Tyler, S.W., Clement, T.P, .Villholth, K.G., Perera, A.P.G.R.L., Obeysekera, J., Gunatilaka, A., Panabokke, C.R, Hyndman, D.W., Cunningham, K.J., Kaluarachchi, J.J., Yeh, W.W-G., van Genuchten, M.Th., Jensen, K., 2006. Impacts of the 2004 tsunami on groundwater resources in Sri Lanka. Water Resour. Res., 42, W05201. DOI: 10.1029/2006WR004876.

Jocson, J.M. U., Jenson, J.W., Contractor, D.N., 2002. Recharge and aquifer response: northern Guam lens aquifer, Guam, Mariana Islands. Journal of Hydrology, 260, 1, 231254.

Kamps, P.W.J.T., Nienhuis, P., Witte, J.P.M., 2008. Effects of climate change on the water table in the coastal dunes of the Amsterdam Water Supply. In: Proceedings MODFLOW.

Leterme, B., Gedeon, M., Jacques, D., 2013. Groundwater recharge modeling of the Nete catchment (Belgium) using the HYDRUS 1D - MODFLOW package. In: Šimůnek, J., M.Th. van Genuchten, Kodešová, R. (Eds.): Proc. of the 4th International Conference "HYDRUS Software Applications to Subsurface Flow and Contaminant Transport Problems, Prague, Czech Republic, pp. 235-244. ISBN: 978-80-2132380-3

Leterme, B., Gedeon, M., Laloy, E., Rogiers, B., 2015. Unsaturated flow modeling with HYDRUS and UZF: calibration and intercomparison. In: Proc. MODFLOW and More 2015. Integrated GroundWater Modeling Center, May 31-June 3, 2015, Golden, CO.

Luoma, S., Okkonen, J., 2014. Impacts of future climate change and Baltic Sea level rise on groundwater recharge, groundwater levels, and surface leakage in the Hanko aquifer in southern Finland. Water, 6, 12, 3671-3700.

Mahmoodzadeh, D., Ketabchi, H., Ataie-Ashtiani, B., Simmons, C.T., 2014. Conceptualization of a fresh groundwater lens influenced by climate change: A modeling study of an arid-region island in the Persian Gulf, Iran. Journal of Hydrology, 519, 399-413.

Meyer, P.D., Rockhold, M.L., Gee, G.W., 1997. Uncertainty analyses of infiltration and subsurface flow and transport for SDMP sites. Rep. NUREG/CR-6565, PNNL-11705. U.S. Nuclear Regulatory Commission, Washington, DC.

Mollema, P.N., Antonellini, M., 2013. Seasonal variation in natural recharge of coastal aquifers. Hydrogeology Journal, 21, 4, 787-797.

Neitsch, S.L., Williams, J.R., Arnold, J.G., Kiniry, J.R., 2011. Soil and water assessment tool theoretical documentation version 2009. Texas Water Resources Institute, College Station, TX

Neuman, S.P., Feddes R.A., Bresler, E., 1974. Finite element simulation of flow in saturated-unsaturated soils considering water uptake by plants. Third Annual Report, Project No. A10-SWC-77. Hydraulic Engineering Lab., Technion, Haifa, Israel.

Niswonger, R.G., Prudic, D.E., Regan, R.S., 2006. Documentation of the unsaturated-zone flow (UZF1) package for modeling unsaturated flow between the land surface and the water table with MODFLOW-2005 (No. 6A19).

Oude Essink, G.H.P., Van Baaren, E.S., De Louw, P.G., 2010. Effects of climate change on coastal groundwater systems: a modeling study in the Netherlands. Water Resources Research, 46, 10.

Persson, M., Saifadeen, A., 2016. Effects of hysteresis, rainfall dynamics, and temporal resolution of rainfall input data in solute transport modelling in uncropped soil. Hydrological Sciences Journal, 61, 5, 982-990.

Prieto, C., Kotronarou, A., Destouni, G., 2006. The influence of temporal hydrological randomness on seawater intrusion in coastal aquifers. Journal of Hydrology, 330, 1, 285-300.

Sadurski, A., Borawska, J., Burczyk, T., 1987. Warunki hydrogeologiczne i hydrochemiczne Mierzei Helskiej [Hydrogeological and hydrochemical conditions of Hel Peninsula.] Kwartalnik Geologiczny, 31, 4, 767-782. (In Polish.)

Scanlon, B.R., Christman, M., Reedy, R.C., Porro, I., Šimůnek, J., Flerchinger, G.N., 2002. Intercode comparisons for simulating water balance of surficial sediments in semiarid regions. Water Resources Research, 38, 12, 1323. DOI: 10.1029/2001WR001233.

Schroeder, P.R., Dozier, T.S., Zappi, P.A., McEnroe, B.M., Sjostrom, J.W., Peton, R.L., 1994. The Hydrologic Evaluation of Landfill Performance (HELP) Model: Engineering Documentation for Version 3, EPA/600/R94/168b. US. Environmental Protection Agency, Risk Reduction Engineering Laboratory, Cincinnati.

Seo, H.S., Šimůnek, J., Poeter, E., 2007. Documentation of the HYDRUS Package for MODFLOW-2000, the U.S. Geological Survey Modular Ground-Water Model, GWMI 2007-01. International Ground Water Modeling Center, Colorado School of Mines, Golden, Colorado, $96 \mathrm{p}$.

Šimůnek, J., Jarvis, N. J., van Genuchten, M.Th., Gärdenäs, A., 2003. Review and comparison of models for describing nonequilibrium and preferential flow and transport in the vadose zone. Journal of Hydrology, 272, 1, 14-35.

Šimůnek, J., Šejna, M., Saito, H., Sakai, M., van Genuchten, M.Th., 2008a. The HYDRUS-1D software package for simulating the one-dimensional movement of water, heat, and multiple solutes in variably-saturated media, Version 4.0. HYDRUS Software Series 3. Department of Environmental Sciences, University of California, Riverside, CA, USA, $315 \mathrm{p}$.

Šimůnek, J., van Genuchten, M.Th., Šejna M., 2008 b. Development and applications of the HYDRUS and STANMOD software packages and related codes. Vadose Zone Journal, 7, 2, 587-600.

Šimůnek, J., van Genuchten, M.Th., Šejna, M., 2016. Recent developments and applications of the HYDRUS computer software packages. Vadose Zone Journal, 15, 7, 25 p. DOI: 10.2136/vzj2016.04.0033.

Sinclair, P., Galvis, S.C., Bosserelle, A.L., Post, V.E.A., Werner, A., 2016. Sustainability of freshwater lenses in atoll 
environments. In: Proceedings of 24th Salt Water Intrusion Meeting and the 4th Asia-Pacific Coastal Aquifer Management Meeting, 4-8 July 2016, Cairns, Australia.

Smerdon, B.D., Mendoza, C.A., Devito, K.J., 2008. Influence of subhumid climate and water table depth on groundwater recharge in shallow outwash aquifers. Water Resources Research, 44, W08427.

Stuyfzand, P.J., 2016. Formation and hydrogeochemistry of a freshwater lens on a sandbar island in saltwater lake Grevelingen, Netherlands. In: Proceedings of 24th Salt Water Intrusion Meeting and the 4th Asia-Pacific Coastal Aquifer Management Meeting, 4-8 July 2016, Cairns, Australia.

Sulzbacher, H., Wiederhold, H., Siemon, B., Grinat, M., Igel, J., Burschil, T., Günther, T., Hinsby, K., 2012. Numerical modelling of climate change impacts on freshwater lenses on the North Sea Island of Borkum using hydrological and geophysical methods. Hydrology and Earth System Sciences, 16, 10, 3621-3643.

Szymańska, P., Tisler, W., Schütz, C., Szymkiewicz, A., Neuweiler, I., Helmig, R., 2016. Experimental and numerical analysis of air trapping in a porous medium with coarse textured inclusions. Acta Geophysica, 64, 6, 24872509.

Therrien, R., McLaren, R. G., Sudicky, E. A., Panday, S. M., 2010. HydroGeoSphere: A three-dimensional numerical model describing fully-integrated subsurface and surface flow and solute transport. Groundwater Simulations Group, University of Waterloo, Waterloo, ON.

Thoms, R.B., Johnson, R.L., Healy, R.W., 2006. User's guide to the Variably Saturated Flow (VSF) process for MODFLOW. Techniques and Methods 6-A18. US Geological Survey, Reston, VA.

Trglavcnik, V., Robinson, C., Morrow, D., White, D., Paquin, V., Weber, K., 2016. Effect of tides, waves and precipitation on groundwater flow dynamics on Sable Island, Canada. In: Proceedings of 24th Salt Water Intrusion Meeting and the $4^{\text {th }}$ Asia-Pacific Coastal Aquifer Management Meeting, 4-8 July 2016, Cairns, Australia.
Twarakavi, N.K.C., Šimůnek, J., Seo, H.S., 2008. Evaluating interactions between groundwater and vadose zone using HYDRUS-based flow package for MODFLOW. Vadose Zone Journal, 7, 2, 757-768.

Vandenbohede, A., Mollema, P.N., Greggio, N., Antonellini, M., 2014. Seasonal dynamic of a shallow freshwater lens due to irrigation in the coastal plain of Ravenna, Italy. Hydrogeology Journal, 22, 4, 893-909.

Vero, S.E., Ibrahim, T. G., Creamer, R. E., Grant, J., Healy, M. G., Henry, T., Kramers, G., Richards, K.G., Fenton, O. 2014. Consequences of varied soil hydraulic and meteorological complexity on unsaturated zone time lag $\overline{\text { estimates. Journal of Contaminant Hydrology, }} \frac{170}{53-67}$.

Verruijt, A., 1968. A note on the Ghyben-Herzbeg formula. International Association of Scientific Hydrology Bulletin, 13, 4, 43-46. DOI: 10.1080/02626666809493624.

Voss, C.I., Provost, A.M., 2010. SUTRA: A model for saturated-unsaturated, variable-density groundwater flow with solute or energy transport. USGS Water- Resources Investigations Report, 02-4231, U.S. Geological Survey, Reston, VA

Werner, A.D., Lockinton, D.A., 2004. The potential for soil salinization above aquifers influenced by seawater intrusion. In: Proc. 13th International Soil Conservation Conference, Brisbane, paper No. 790.

Werner, A.D., Bakker, M., Post, V.E., Vandenbohede, A., Lu, C., Ataie-Ashtiani, B., Simmons, C.T., Barry, D.A., 2013. Seawater intrusion processes, investigation and management: recent advances and future challenges. Advances in Water Resources, 51, 3-26.

Winston, R.B., 2009. ModelMuse: a graphical user interface for MODFLOW-2005 and PHAST. US Geological Survey, Reston, VA.

Received 19 June 2017 Accepted 10 January 2018 